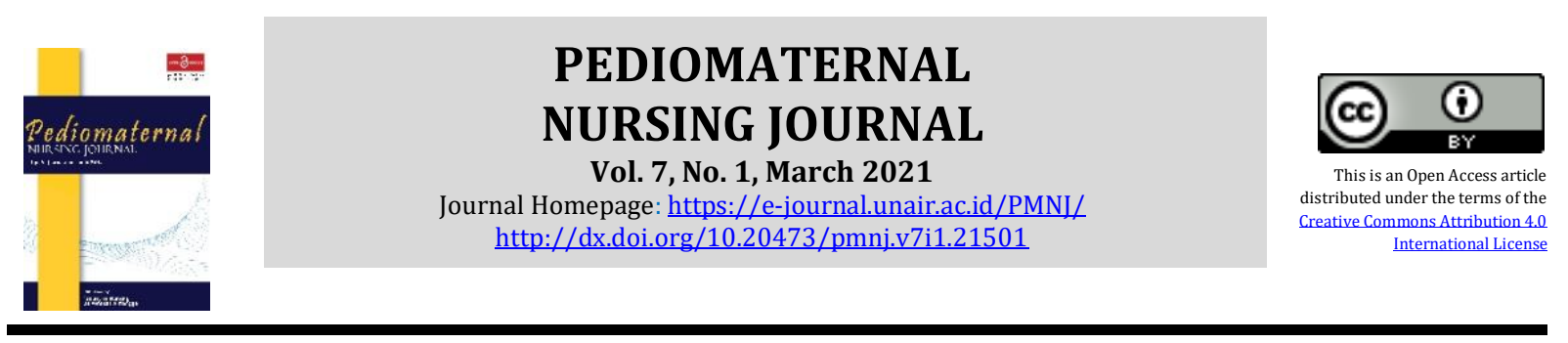

Original Research

\title{
Feeding Behavior Among Stunting Toddler's Mothers
}

\author{
Silvia Farhanidiah, Yuni Sufyanti Arief $\mathbb{B}$, Iqlima Dwi Kurnia \\ Maternity and Pediatric Nursing Department, Faculty of Nursing, Universitas Airlangga, Surabaya, Indonesia
}

\author{
ARTICLE HISTORY \\ Received: August 20, 2020 \\ Accepted: January 23, 2021 \\ Published: July 18, 2021
}

\section{KEYWORDS}

Stunting; feeding behaviour; knowledge; attitude; practice

CORRESPONDING AUTHOR

Yuni Sufyanti Arief yunisa@fkp.unair.ac.id Faculty of Nursing, Universitas Airlangga, Surabaya, Indonesia

Cite this as:

\begin{abstract}
Introduction: Stunting is the accumulation of nutritional deficiency in a long time. This research has the objective to describe the knowledge, attitude, and action of feeding in stunting toddlers mothers in the Work Area of Tambak Wedi Public Health Center Surabaya.

Methods: A descriptive observational study design was used. The population of this research was mothers who have stunting toddlers with total of 65 respondents. The sample total of this research was 60 respondents proportional sampling technique. The data was analyzed using descriptive analysis.

Results: The result of this research shows that 37 respondents $(61.6 \%)$ have less knowledge, 44 respondents (58.3\%) have negative attitude and 35 respondents $(58.3 \%)$ have inappropriate action.

Conclusion: Behavior of feeding by the mother affects the status of the toddler, so it needs to increase mother's knowledge, attitude, and action about feeding in toddlers. This research suggests that Public Health Center should provide information about feeding to stunting toddlers through health promotion activity.
\end{abstract}

Farhanidiah, S., Arief, Y, S., \& Kurnia, I, D. (2021). Feeding Behavior Among Stunting Toddler's Mothers. Pediomaternal Nurs. J., 7(1), 26-32. Doi: http://dx.doi.org/10.20473/pmnj.v7i1.21501

\section{INTRODUCTION}

The stunting prevalence from 2013 to 2018 did not show a significant decrease (Riset Kesehatan Dasar (Riskesdas), 2018). Incorrect feeding behaviour is one of the factors that caused in the stunting incident in Work Area Tambak Wedi Surabaya (Prakhasita, 2019). Nutritional Education to parents and families who have children can change their behaviour from the family especially in feeding (Olsa \& Edwin, 2017). The stunting prevalence in Indonesia is ranked at 108 from 132 countries (Global Nutrition Report, 2014) The prevalance of stunting toddlers in Indonesia is the highest than Myanmar (35\%), Vietnam (23\%), Malaysia (17\%), Thailand (16\%), and Singapura (4\%). The percentage of stunting in 2018 is $30.8 \%$ or about 7 million stunting toddlers (Riset Kesehatan Dasar (Riskesdas), 2018). According to the interview with toddler's mothers, it is gotten the data that 6 from 10 toddlers mothers have less knowledge about Early Breastfeeding Initiation (IMD), Breast Milk (ASI), and 
Complementary Foods of Breast Milk (MPASI). Besides that, 5 from 10 toddlers mothers do not give exclusive breast milk (ASI Eksklusif) and too early in giving the complementary foods of breast milk.

The low of right feeding practice is related to the knowledge, attitude, and practice of the mothers. One of the difficulty factors in handling the nutrition in Indonesia is inadequate knowledge of mother or baby sitter and incorrect practice in feeding (UNICEF, 2012). The lack of nutrition intake for a long time can cause stunting (Damayanti, R. A., Muniroh, L, 2016). Stunting can influence the intelligence level, susceptibility of the disease, decreasing of productivity, hampering economic growth, and increasing the poverty and inequality (UNICEF FRAMEWORK, 2007).

The forming factors of health behaviours, there are many factors can influence the forming of feeding attitude from mothers to toddlers such as: predisposing factors, enabling factors, and reinforcing factors. In the predisposing factors, there are many dimensions such knowledge dimension, attitude, feeling, and confidence which all of those dimensions will influence person to change individual attitude. Thus, it shows that the knowledge level of mothers about feeding will influence the attitude and action of mothers in the practice of feeding to the mother well and right (Lawrence Green, 1991). According to that explanation, this research has the objective to describe the knowledge, attitude, and action of feeding in stunting toddlers mothers in the Work Area of Tambak Wedi Public Health Center Surabaya.

\section{METHOD}

\subsection{Design}

The kind of this research is descriptive observational. The objective of this research is to describe the knowledge, attitude, and action in the feeding of stunting toddler mothers in the Work Area of Tambak Wedi Public Health Center Surabaya.

\subsection{Population, Samples, and Sampling}

The population in this research is mothers with stunting toddlers in Work Area Public Health Center Tambak Wedi Surabaya,
Kenjeran Sub District, Surabaya City with a total of 65 respondents. The large sample is according to inclusion criteria and exclusion criteria with a total of 60 respondents. The sampling technique in this research is used non-probability sampling technique with proportional sampling type.

\subsection{Procedure}

The data is collected online by using google form. First on February 2020, researchers do the contract about the research time contract with nutritionists and the cader of Integrated Health Service Post (Kader Posyandu). Before doing the research, on March 2020 the researcher counts the total of the sample and the technique of taking the sample. Then, on May 2020 researcher shares the google form link about informed consent. Respondents are given the freedom of rights to join the participation or refuse the research activity. The respondents who are ready in the research. Then, continue to the next section such as: filling the demographic data and questions about the knowledge, attitude, and action of feeding. It took a week to finish collecting the google form data.

\subsection{Analysis}

The collected data is analyzed by using analysis descriptive, to find out the percentage and frequency distribution of knowledge, attitude, and action of stunting toddler's mothers feeding behaviour.

\subsection{Ethical Clearance}

This research has been done by reviewing the ethic from The Research Ethic Commission from Faculty of Nursery, Airlangga University Surabaya with number 1995-KEPK. The ethical aspects which are considered to this research such informed consent, anonymity, and confidentiality.

\section{RESULT}

The mother characteristics are shown on table 1. Many respondents from 26 to 35 years old are $39(65 \%)$. The last educational background of respondents is Senior High School/ equality such as 26 (43.3\%). Most respondents are not working with a total of 45 (75\%). The most responden has one child are $26(43.3 \%)$. The income of more 
Table 1. The Demographic Characteristics of Stunting Toddler Mother Respondents in the Work Area of Tambak Wedi Public Health Center Surabaya Year 2020

\begin{tabular}{|c|c|c|c|}
\hline Characteristics & Indicators & $\mathbf{n}$ & $\%$ \\
\hline \multirow[t]{3}{*}{ Ages } & 17-25 Years & 8 & 13.3 \\
\hline & 26-35 Years & 39 & 65 \\
\hline & 36-45 Years & 13 & 21.7 \\
\hline \multirow[t]{4}{*}{ Educations } & Elementary School/ Equality & 13 & 21.6 \\
\hline & Junior High School/ Equality & 12 & 20 \\
\hline & Senior High & 26 & 43.3 \\
\hline & School/Equality University & 9 & 15.1 \\
\hline \multirow[t]{5}{*}{ Professions } & Not working & 45 & 75 \\
\hline & Enterpreneur/Seller & 7 & 11.6 \\
\hline & Civil Servant & 0 & 0 \\
\hline & General Employee & 8 & 13.4 \\
\hline & Others & 0 & 0 \\
\hline \multirow[t]{4}{*}{ The Total of Children } & 1 & 26 & 43.3 \\
\hline & 2 & 22 & 36.5 \\
\hline & 3 & 11 & 18.3 \\
\hline & 4 & 1 & 1.9 \\
\hline \multirow[t]{3}{*}{ Family Incomes } & $<4,200,729$ & 45 & 75 \\
\hline & $4,200,729$ & 7 & 11.6 \\
\hline & $>4,200,729$ & 8 & 13.4 \\
\hline The Total of Family & 3 & 18 & 30 \\
\hline \multirow[t]{3}{*}{ Members } & 4 & 26 & 43.3 \\
\hline & 5 & 12 & 20 \\
\hline & 6 & 4 & 6.7 \\
\hline
\end{tabular}

Table 2. The Demographic Characteristic of Stunting Toddler in Working Area of Tambak Wedi Public Health Center Surabaya Year 2020

\begin{tabular}{llccc}
\hline \multicolumn{1}{c}{ Characteristics } & Indicators & n & \% \\
\hline Toodler Ages & 12-36 Months & 34 & 56.7 \\
& 37-60 Months & 26 & 43.3 \\
Gender & Male & 30 & 50 \\
& Female & 30 & 50 \\
\multirow{2}{*}{ Stunting Categories } & Short & 37 & 61.6 \\
& Very Short & 23 & 38.4 \\
\hline
\end{tabular}

Table 2. The Distribution of Frequency Distribution Knowledge, Attitude, and Action of feeding stunting toddlers mothers in Work Area of Tambak Wedi Public Health Center Surabaya Year 2020

\begin{tabular}{llccc}
\hline \multicolumn{1}{c}{ Variables } & & Category & n & \% \\
\hline Knowledges & Less & 37 & 61.7 \\
& Enough & 23 & 38.3 \\
& Good & 0 & 0 \\
Attitudes & Negative & 44 & 73.3 \\
& Positive & 16 & 36.7 \\
Actions & Incorret & Correct & 35 & 58.3 \\
& & 25 & 41.7 \\
\hline
\end{tabular}

respondents is under Regional Minimum Wage (UMR) of Surabaya City $<4200.729$ is $45(75 \%)$. The most responden has four total family members are $26(43.3 \%)$ (Table 1 ).

Table 2 shows toddlers characteristics are shown based on table 2. Most of the toddlers from 12 years to 36 years month such as 34 (56.7\%). The gender of the most toddlers from 12 to 36 months is female with a total of $30(50 \%)$ and most of them are male with a total of $30(50 \%)$. Most of the toddlers are categorized as stunting such as short with a total of 37 (61.6\%).

According to table 3, it is known that The distribution of knowledge, attitude, and action of respondents are shown on table 3 . According to the result most of the respondents have less knowledge with a total of 37 (61.7\%), most of the respondents have the negative attitude with a total of 44 (73.3.\%) and most of the respondents have incorrect action with a total of 35 (58.3\%). 


\section{DISCUSSION}

\subsection{The Knowledge of Feeding in Stunting Toddler's Mother in Work Area Public Health Center Tambak Wedi Surabaya}

The result about the distribution of respondent's knowledge show that most of the respondents know with less related indicators category about Early Breastfeeding Initiation, Exclusive Breastfeeding, Complementary Foods of Breastfeeding, and the importance of giving breastfeeding up to 24 months.

The knowledge is the sensing result and someone's experience which are influenced by the intensity of human attention to objects. The aim is to extend the horizon will produce knowledge. (Yuliana, 2017) The knowledge is explained in the cognitive domain has six levels such now, comprehension, application, analysis, synthesis, and evaluation (Notoatmojo, 2014) The knowledge level of someone is influenced by many factors such age, education, experience, environment, parents, book, intelligence, mass media exposure, social, economy, and culture (Notoatmojo, 2012)

The less nutrition in the developing country happens because inappropriate of feeding patterns (Ningsih, Kristiawati, \& Krisna, 2015). The low level of feeding in baby and children are very related to the knowledge, attitude, and practice of mothers. The inadequate knowledge of mothers or babysitters and the practice of improperly in feeding is one of the difficult factors in handling the lack of nutrition in Indonesia (UNICEF FRAMEWORK, 2007). The feeding pattern is given to the toddler will influence to the toddler's growth process. Because the nutrition intake contains substantial things to growth, healthy, and intelligence (UNICEF, 2012). The given feeding pattern to the toddler will influence the growth of the toddler because the nutrition intake contains important nutrients to growth, healthy, and intellegence (Purwani \& Maryam, 2013). The fulfillment pattern of nutritional status in children is one of the efforts to fulfill the basic needs of children about hone, love, and foster care (Rachmawati, Ranuh, \& Arief, 2016).

According to this research, it is gotten the data that the knowledge of respondents about majority feeding is categorized as less.
Although there are some respondents have enough knowledge, the statistical result showed that the lowest in achieving score on several aspects such as: about the frequency of giving complementary feeding of breast milk (MPASI) on the baby from 6 to 9 months, the importance of continue in giving ASI to the children up to 24 months, the frequency of giving complementary feeding of breast milk (MPASI) to the children from 12 to 24 months, the definition of colostrum, and the benefits of Early Breastfeeding Initiation (IMD).

\subsection{The Attitude in Feeding of Stunting Toodler's Mother in Work Area of Tambak Wedi Public Health Center Surabaya}

The result of the respondent's distribution attitude shows that most of the respondents have an attitude in the negative category about indicators of early breastfeeding, exclusive breastfeeding, complementary food of breastfeeding, and the importance of giving the breastfeeding up to 24 months.

The attitude is the reaction or someone's response which is still enclosed to the stimulus or object. The attitude consists of many levels such as: receiving, responding, valuing, and responsible (Notoatmojo, 2014). According to Lawrence Green 1976 in (Nursalam, 2017) explain that someone's attitude includes the predisposing factor which comes from themselves. According to (Pusparini \& Arifah, 2009)show that knowledge and attitude are very related. The higher education then respondents get the information easily. (Azwar, 2013) explains that there are many factors influence someone's attitude such personal experience, the influence of important people, culture, mass media, educational institution, religious institution, and emotional.

According to that case, the respondent's knowledge is categorized as less. Thus, it causes respondent's attitude get into the negative category. It is proven based on the statistic result about the lowest score to some aspects such as: choose in giving formula milk than breast milk in the children more than 6 months, not giving exclusive breast milk to the baby from 0 to 6 months, give side dishes of breast milk to the baby less than 6 months, not continuing to feed breast milk for children up to 2 years old, not giving the 
variation of side dishes foods of breast milk (MPASI), and not doing skin contact to the baby born.

\subsection{The Action of Feeding of Stunting Toddler's Mother in Work Area of Tambak Wedi Public Health Center Surabaya}

The research result about the distribution of action or respondents behaviour shows that most respondents have action or attitude with incorrect categories related to the total food indicator, the kind of food, and the schedule of eating.

Behavioural factors and non behavioural factors cause the action of health (Green \& Kreuter, 1991). Behavioural factors such predisposition and enabling. The predisposition factor is the inherent character to the individual about confidence attitude, value, motivation, and knowledge. According to (Glanz, Rimer, \& Viswanath, 2008), the behaviour is the embodiment of someone subjective value to the reach of expected results which are doing with certain actions to reach the result.

According to this research, it is gotten data that most of the respondents have incorrect action. It is proven to the statistic result that the reach lowest score to some aspects such as: not making the eating schedule of the children, not getting used to eating on time, getting children to eat more than 30 minutes, not giving fruits to the children everyday, not getting used to ingest foods, and not giving a right portion of rice to the children.

Most of the toodler's mothers under two years old in Kenagarian Simpang Pasaman Regency have the incorrect attitude about the practice of feeding side dishes of breast milk which is related to research of (Annisa, 2017). According to the research (Priyono, Sulistiyani, \& Ratnawati, 2015) stunting toddler nutritional status is the accumulation of previous eating habits. Thus, the feeding patterns on certain days cannot influence their nutritional status directly. According to (Suhardjo, 2003), the success key to fulfilling nutrition to children is located on their mother. The good eating habit is very dependent on the knowledge and mother skill about the way to arrange the foods which fulfill the nutrient requirement.

There are many factors to influence someone in doing behaviour or action.
Precede- Proceed Theory explains that three factors such as: predisposing factors, enabling factors, and reinforcing factors can influence the change of someone behaviour (Green, 1991). Predisposing factors are the factor from individuals which influence their desire to change the confidence, social economy, and others. Enabling factors are the probable factor or facilitate someone behaviour such as: available and easy access to health care facility, government regulation, and others. Then, reinforcing factor is the factor which strengthens the occurrence behaviours such as: incentive or penalty, family social support, friend, health worker's attitude, etc (Green, 1991).

The result of this research shows that the knowledge and respondent's attitude about feeding still less. It is showed that predisposing factors such knowledge and attitude can become one of the factors influences the respondents to have inappropriate action and social economy factor also one of the factor influence the stunting toodler's mothers action, because most mothers have income under the Regional Minimum Wage (UMR).

\section{CONCLUSION}

According to the research to stunting toddler's mothers in the Working Area of Health Public Center Tambak Wedi in 2020 that the respondent ages include to early adulthood group. It is from 26 to 35 years old. The result shows that the level of knowledge to the respondent is less, especially in the indicator of frequency in giving the complementary feeding of breast milk (MPASI). Meanwhile the attitude is in negative category, especially in the indicator of frequency in giving MPASI.Then the action showed incorrect result, especially in the feeding total indicators. Researchers suggest that further researchers develop audiovisual media as an alternative tool that can improve feeding behavior and can directly observe mothers and toddlers so that the data obtained is more detailed.

\section{ACKNOWLEDGEMENT}

We want to say thank you for the respondents and all of the participants who help in the implementation of this research. 


\section{CONFLICT OF INTEREST}

The authors declare that there is no conflict of interest

\section{REFERENCES}

Annisa, Z. A. (2017). Pengaruh Konseling Gizi Terhadap Pengetahuan Ibu Dan Praktek Pemberian Makanan Pendamping Air Susu Ibu Baduta Stunting Di Kenagarian Simpang Kabupaten Pasaman Tahun 2017. Universitas Andalas.

Azwar, S. (2013). Sikap Manusia: Teori dan Pengukurannya. Yogyakarta: Pustaka Pelajar. https://doi.org/10.1038/cddis.2011 .1

Camci, N., Bas, M., \& Buyukkaragoz, A. H. (2014). The psychometric properties of the Child Feeding Questionnaire (CFQ) in Turkey. Appetite, Elsevier L, 49-54.

https://doi.org/10.1016/j.appet/20 14.03.009

Damayanti, R. A., Muniroh, L, F. (2016). Perbedaan Tingkat Kecukupan Zat Gizi dan Riwayat Pemberian Asi Ekslusif Pada Balita Stunting dan NonStunting. Media Gizi Indonesia, II(1), 61-69.

Dewi, M., \& Aminah, M. (2016). Pengaruh Edukasi Gizi terhadap Feeding Practice Ibu Balita Stunting Usia 6-24 Bulan (The Effect of Nutritional Knowledge on Feeding Practice of Mothers Having Stunting Toddler Aged 6-24 Months). Indonesian Journal of Human Nutrition, 3(1), 1-8.

Fitria, W. (2013). Karakteristik Ibu Menyusui yang Tidak Memberikan ASI Eksklusif di UPT Puskesmas Banyudono I Kabupaten Boyolali. INFOKES, 3(2).

Glanz, K., Rimer, B. K., \& Viswanath, K. (2008). Health Behavior and Health Education: Theory, Research and
Practice (4th Editio). San Fransisco: JosseyBass.

Global Nutrition Report. (2014). Actions and Accountability to Accelerate the World's Progress on Nutrition. International Food Policy Research Institute. Washington, $D C$.

Green, L. W. (1991). Health Promotion Planning an Educational \& Environmental Approach. Second Edition: Mayfield Publishing Company.

Green, L. W., \& Kreuter, M. W. (1991). Health Promotion Planning an Education and Environmental Approach. Mountain View, California: Mayfield Publishing.

Liestyawati, L. (2018). Pengaruh Penyuluhan Dengan Media Booklet Terhadap Pengetahuan Dan Sikap Ibu Baduta Tentang Pemberian Makan Bayi Dan Anak (Pmba) Di Desa Kemusu Kecamatan Kemusu Kabupaten Boyolali. Surakarta: Program Studi Ilmu Gizi Fakultas Ilmu Kesehatan Universitas Muhammadiyah Surakarta.

Ningsih, S., Kristiawati, \& Krisna, I. (2015). Hubungan Perilaku Ibu Dengan Status Gizi Kurang Anak Usia Toodler. Jurnal Pediomaternal, 3(1), 58-65.

https://doi.org/10.1017/CB097811 07415324.004

Notoatmojo, S. (2012). Promosi kesehatan dan ilmu perilaku. Jakarta: Rineka cipta.

Notoatmojo, S. (2014). Kesehatan Masyarakat Ilmu \& Seni. Jakarta: Rineka Cipta.

Nursalam. (2017). Metodologi Penelitian Ilmu Keperawatan: Pendekatan Praktis. Jakarta: Salemba Medika.

Olsa, \& Edwin. (2017). Hubungan Sikap dan Pengetahuan Ibu Terhadap 
Kejadian Stunting pada Anak Baru Sekolah Dasar di Kecamatan Nanggalo. Jurnal FK UNAND: Fakultas Kedokteran Universitas Andalas Padang.

Prakhasita, R. C. (2019). Hubungan Pola Pemberian Makan Dengan Kejadian Stunting Pada Balita Usia 12-59 Bulan Di Wilayah Kerja Puskesmas Tambak Wedi Surabaya. Universitas Airlangga.

Priyono, D. I. P., Sulistiyani, \& Ratnawati, L. Y. (2015). Determinan Kejadian Stunting pada Anak Balita Usia 12-36 Bulan di Wilayah Kerja Puskesmas Randuagung Kabupaten Lumajang. EJurnal Pustaka Kesehatan, 3(2), 349355.

Purwani, \& Maryam. (2013). Pola Pemberian Makan Dengan Status Gizi Anak Usia 1 Sampai 5 Tahun Di Kabunan Taman Pemalang. Jurnal Keperawatan Anak, 1(1), 30-36.

Pusparini, W., \& Arifah, S. (2009). Hubungan Pengetahuan Ibu Tentang Toilet Trainning Dengan Perilaku Ibu Dalam Melatih Toilet Training. 105111.

Rachmawati, P. D., Ranuh, R., \& Arief, Y. (2016). Model Pengembangan Perilaku Ibu dalam Pemenuhan Kebutuhan Asah, Asih dan Asuh Anak
Leukemia. Jurnal Ners, 11(1), 63-72.

Riset Kesehatan Dasar (Riskesdas). (2018). No Title. Retrieved from http://www.depkes.go.id/resources /download/infoterkini/materi_rako rpop_20 18/Hasil Riskesdas 2018.pdf - Diakses Agustus 2018.

Sari, F. (2017). Hubungan Pemberdayaan Masyarakat melalui Pelatihan Pemberian Makan pada Bayi dan Anak (PMBA) terhadap Status Gizi Bayi dibawah Dua Tahun (BADUTA) di Desa Pandes Wedi Kabupaten Klaten. Yogyakarta: Sekolah Tinggi Ilmu Kesehatan Guna Bangsa Yogyakarta.

Suhardjo. (2003). Berbagai cara pendidikan gizi. Jakarta: Bumi Aksara.

UNICEF. (2012). United Nation Children Fund Indonesia. Ringkasan Kajian Gizi Ibu dan Anak: isu-isu penting. 2012.

UNICEF FRAMEWORK. (2007). $A$ schematic overview of the factors known from international experience to cause chronic malnutrition, or stunting.

Yuliana, E. (2017). Bab II Kajian Pustaka. Retrieved from http://repository.ump.ac.id/4114/3 /Erlin Yuliana_BAB II.pdf. 